\title{
KLRB1 wt Allele
}

National Cancer Institute

\section{Source}

National Cancer Institute. KLRB1 wt Allele. NCI Thesaurus. Code C51312.

Human KLRB1 wild-type allele is located within 12p13 and is approximately $13 \mathrm{~kb}$ in length. This allele, which encodes HNKR-P1a protein, is involved in natural killer cell function. 